\title{
The Charter of Fundamental Rights
}

\author{
SIR BERNARD MCCLOSKEY
}

\subsection{Introduction}

The law of unintended consequences specializes in conundrums and anomalies. The Charter of Fundamental Rights of the European Union (CFR) was singled out for special, targeted attention in the UK domestic Brexit legislation. ${ }^{1}$ The evident intention of the UK government - abrupt and permanent extinction of the CFR from UK law - was unmistakable. The European Union (Withdrawal) Act 2018 (EUWA 2018) repealed the European Communities Act 1972, the measure of primary legislation whereby the UK acceded to the EU, while converting existing EU law into domestic law, subject to specified exceptions. The CFR is one of the most striking of these exceptions, by virtue of section 5(4) EUWA 2018, which provides: 'The Charter of Fundamental Rights is not part of domestic law on or after exit day.' Thus, the CFR, it seemed, ceased to form part of domestic UK law overnight, permanently and without more. But the story does not end there. The multiple components of the Brexit legal architecture, not less than complex, having been finalized and activated, it is not clear that this apparent intention has been achieved. If it was not, was this by accident or by design?

\subsection{The DNA of the CFR}

Human rights development in EU law has been the product of evolution, not revolution: a gentle, orderly and judge-led process which, viewed in retrospect, appears a natural progression. It is nonetheless remarkable given that human rights did not feature in the Treaties in their original incarnation. There was no bill of rights and nothing equivalent thereto. The founding fathers were enlightened and ambitious, but cautiously so.

${ }^{1}$ For an overview of this legislation, see Chapters 3 and 9. 
The Lisbon reforms of 2009, which made the CFR enforceable EU law, effected a significant transformation of the EU landscape, with a greater emphasis on human rights protection in the Treaties than ever before. The CFR represented the culmination of several decades' work of the Court of Justice of the European Union (CJEU) and its predecessor (the European Court of Justice (ECJ)) during which active, imaginative and penetrating judicial interpretation and application of EU law had discovered and proclaimed fundamental rights, ${ }^{2}$ initially through the conduit of 'general principles' considered to be inherent in the Treaties and subsequently by explicit recognition in the Treaties themselves. Article 6(3) of the Treaty on European Union (TEU) provides that fundamental rights shall constitute general principles of EU law. It proclaims that 'fundamental rights' consist of those rights guaranteed by the European Convention of Human Rights and Fundamental Freedoms (ECHR), together with rights embedded in the constitutional traditions common to the member states. ${ }^{3}$

The CFR represents both the vindication and the codification of the jurisprudence of the CJEU, which from its earliest days developed the cornerstone principles of equal treatment, non-discrimination, transparency, legitimate expectations and the legal recognition and protection of other fundamental rights and freedoms. The fundamental difference between the pre-CFR and post-CFR eras is that the rights of EU citizens and others residing on EU territory are now proclaimed and codified visibly and unambiguously in a model which is transparent, unequivocal and dynamic. These rights are more concrete, tangible and accessible than ever before. Constituting one of the three dominant instruments of governance of the EU, the CFR is a legally binding bill of rights, resembling the catalogues of rights to be found in the constitutions of most EU member states. Upon its adoption, a new era in the EU legal order dawned.

\subsection{The CFR's Preamble}

The Preamble to the CFR is illuminating and instructive. It reveals its diverse origins and sources of inspiration, as well as proclaiming its rationale and aims. It recalls the post-war resolution of the peoples of Europe 'to share a peaceful future based on common values'. It draws on

\footnotetext{
2 In the best common law tradition!

3 See also Art 6(1).
} 
the 'spiritual and moral heritage of the Union', which is founded on the 'indivisible, universal values of human dignity, freedom, equality and solidarity'. Its most important statement, arguably, is the reaffirmation that the Union is 'based on the principles of democracy and the rule of law'.

Through the creation of the twin mechanisms of Union citizenship and an area of freedom, security and justice, the EU 'places the individual at the heart of its activities'. The Preamble emphasizes, on the one hand, the common values of the member states and, on the other, the respect to be accorded to 'the diversity of the cultures and traditions of the peoples of Europe', their national identities and how they are governed at national, regional and local levels. Furthermore, the Preamble explicitly recognizes the principle of subsidiarity, while emphasizing that it is necessary to strengthen the protection of fundamental rights', which derive from 'the constitutional traditions and international obligations common to the Member States, the [ECHR], the Social Charters adopted by the Union and by the Council of Europe and the case law of the Court of Justice of the European Union and of the European Court of Human Rights'. The CFR's close affinity with Article 6(3) TEU in this respect is evident.

\subsection{Has the CFR Really Disappeared from the UK Legal System?}

The answer to this question is no. It is at first blush a surprising answer, given the terms of section 5(4) EUWA 2018. Explaining why this is so requires a two-part analysis. I examine first, in this section, what the status of the CFR is in UK law in areas other than those covered by the Protocol. In Section 13.5, I turn to the position under the Protocol.

As regards the status of the CFR in UK law generally after Brexit, its continuing and future potential to influence domestic UK law arises in several ways. First, the following transitional provisions gave the CFR a limited degree of prospective effect after exit day. The CFR continues to operate, albeit on a short-term basis, insofar as relevant to any proceedings begun, but not finally determined, before a UK court or tribunal prior to exit day. ${ }^{4}$ A court will be able to disapply legislation or quash a relevant act where a challenge relates to something predating exit day and is made within a three-year limitation period. ${ }^{5}$ Any pre-exit day

\footnotetext{
4 EUWA 2018 Sch 8, para 39(3).

5 Ibid, para 39(5).
} 
court decisions quashing an act or decision or disapplying a provision of pre-exit secondary legislation on the ground of incompatibility with one of the general principles of EU law will continue to have effect. ${ }^{6}$

Second, and more importantly, the UK's post-Brexit retreat from EU law will not be abrupt. EU law will continue to form part of domestic UK law as 'retained-EU law'. In particular, certain of the existing rights codified under the CFR will be retained in UK domestic law, such as relating to anti-discrimination rights. Unless and until 'retained-EU law' is repealed, it remains in full force, and repeal is likely to be a gradual, incremental process. Indeed, the complete repeal of retained EU law is unlikely to prove either viable or desirable. The CFR will remain influential in the interpretation of all aspects of this retained EU law which it affects. It will also exert an influence via all retained CJEU jurisprudence in which it features. Courts and tribunals are also specifically empowered to have regard, and give effect, to post-exit day CJEU judgments which do not depart from pre-exit day CJEU judgments. ${ }^{8}$ These may include CFR-related decisions.

Third, the CFR could conceivably make a formal or official reappearance in the event of the exercise of the statutory ministerial power to act so as to prevent, remedy or mitigate any failure of retained EU law to operate effectively or any other deficiency. ${ }^{9}$ The same observation applies to the separate power to make transitional arrangements by secondary legislation. ${ }^{10}$

Fourth, the relationship between the CFR and the CJEU's 'fundamental rights' jurisprudence deriving from EU general principles provides a potentially rich harvest of possibilities for continuing CFR influence. Any fundamental rights or principles under EU law which exist irrespective of the CFR (surely a blurred dividing line?) will be retained in UK domestic law. This gives rise to the possibility of resort to the CFR's 'Explanations' and to CFR jurisprudence (whether that of the CJEU or the UK courts) provided that the CFR's rights identified and recognized express a fundamental right or principle existing irrespective of the CFR. While this may give rise to an untidy and uncertain dichotomy, the significance of this provision is that the CFR is a codifying instrument containing at least some provisions deriving from preceding CJEU

6 EUWA 2018 Sch 1, para 2 and Sch 8, para 39(3).

7 EUWA 2018, ss 5(5), 6 and 7.

8 Ibid, s 6(1)(a) and (2).

9 Ibid, s 7.

10 Ibid, s 23(6) and Sch 8, Pts 3 and 4. 
'fundamental rights' case law. This assessment is fortified by the specific provision in the EUWA 2018 that 'references to the Charter in any case law are, so far as necessary for this purpose, to be read as if they were references to any corresponding retained fundamental rights or principles. ${ }^{11}$ It follows that certain aspects of CJEU jurisprudence with a specific focus on the CFR may continue to exert significant influence in the UK following exit day.

\subsection{The CFR, the CJEU and the ECtHR}

The ECHR belongs to the realm of the Council of Europe (COE), an international organization separate from the EU and governed by its own rules, norms, systems and procedures. Its members include the UK. Continued UK membership of the COE is not at present under threat; nor is the UK's accession to the ECHR, although this has often been mooted in the recent past. Unless or until it is significantly weakened, the Human Rights Act 1998 (HRA) should remain a powerful conduit through which the ECHR and the jurisprudence of the European Court of Human Rights (ECtHR) continue as a significant presence in UK law.

In the search for factors which may provide an effective foil to the foreseeable post-Brexit human rights protection backward slide in the UK, attention may turn to the increasing alignment of the CJEU and the ECtHR. This belongs to a context where the EU en bloc is still committed to acceding to the ECHR. ${ }^{12}$ There has been a progressively discernible jurisprudential dialogue between these two courts. ${ }^{13}$ The 'constitutional traditions common to the Member States', a familiar phrase, has increasing resonance in this context. This 'crosspollination' seems merely logical given the strong association linking ECHR rights, the CFR and the general principles of EU law. ${ }^{14}$ Thus, postBrexit, it is foreseeable that both the CFR and the general principles of EU law, particularly insofar as these have been absorbed within the ECHR and the Strasbourg jurisprudence, will continue to have indirect influence

11 Ibid, s 5(5).

12 See, eg, www.coe.int/en/web/human-rights-intergovernmental-cooperation/accession-of -the-european-union-to-the-european-convention-on-human-rights.

13 See, eg, www.coe.int/en/web/dlapil/-/eu-accession-to-the-echr-how-to-square-the-cir cle-.

14 This is readily identifiable in CJEU decisions such as Case C-411/10, NS v SSHD [2012] 2 CMLR 9, and ECtHR decisions such as MSS v Belgium and Greece, Application no 30696/ 09 [2011] 53 EHRR 2. 
in the UK legal system. This will occur in a context where it is the declared philosophy of the ECtHR to treat the ECHR as a living instrument. ${ }^{15}$ While the concern must be that this influence may be weak, it is also worth recalling that, through judicial resourcefulness prior to the HRA, important provisions of the ECHR achieved recognition in the UK. ${ }^{16}$ There will thus be scope for the CFR to influence the development of the common law by judges, particularly on account of its links with the ECHR.

\subsection{The Protocol and the CFR}

In this section, I shall consider the status of the CFR in the UK in areas covered by the Protocol, one of the intricacies of the legal arrangements giving effect to Brexit. Northern Ireland finds itself in a unique situation being the only part of the UK which, post-Brexit, shares a land border with an EU member state, namely Ireland. All citizens of Northern Ireland are British nationals. Many, by virtue of their place of birth or otherwise, are also nationals of Ireland. This entitles them to hold an Irish passport. The members of this group, being Irish nationals, are EU citizens entitled in principle to all of the associated rights and benefits. ${ }^{17}$ The Protocol forms part of the suite of international agreements between the EU and the UK. By virtue of the Protocol, considered in tandem with the 1998 Agreement, an international treaty to which the UK is party, it would appear that those residing in Northern Ireland, whether Irish citizens or not, have the benefit of a range of protected rights greater than those enjoyed post-Brexit by those resident in other parts of the UK. ${ }^{18}$ The effect and nuances of this will be a matter for future assessment, particularly through judicial decisions.

What is clear is that one of the most striking effects of the Protocol for the population of Northern Ireland is that, via a series of interconnected provisions in the European Union (Withdrawal Agreement) Act 2020 (EUWAA 2020) and the Withdrawal Agreement (WA), including the definition of 'Union law' in Article 2 WA, considered in conjunction with a series of provisions within the Protocol, ${ }^{19}$ there is substantial provision for the continued application of specified aspects of 'Union law' in

\footnotetext{
15 Eg, Tyrer v UK, Application no 5856/72, 25 April 1978, para 31.

${ }^{16} \mathrm{Eg}, R$ (Smith and others) $v$ The Ministry of Defence [1996] 1 ALL ER 257.

17 See Chapter 1.

18 See Chapter 12.

19 Especially Arts 2, 5 and 7-11.
} 
Northern Ireland. From this starting point, it would appear that the UK is continuing to implement certain aspects of Union law post-Brexit, and is obliged to do so.

But how does this relate to the status of the CFR? The indelible starting point must be confronted: by Article 51, the CFR applies only when a member state is acting within the scope of EU law, as interpreted in a series of important decisions of the CJEU. ${ }^{20}$ In general, the UK's institutions will, of course, no longer be doing so. However, bearing in mind Article 51 of the CFR, and notwithstanding section 5(4) EUWA 2018, the CFR - via the Protocol - has achieved a level of survival in respect of Northern Ireland extending beyond the situations and respects identified above in Section 13.5.

The explanation of the foregoing proposition requires a careful examination of several further provisions of the WA, two in particular. The first is Article 4(1): 'The provisions ... of Union law made applicable by this Agreement shall produce in respect of and in the United Kingdom the same legal effects as those which they produce within the Union and its Member States.' Insofar as the WA (which includes, of course, the Protocol) entails the implementation of Union law, the CFR will apply, by virtue of Article 51.

The second is Article 4(2) WA: 'The United Kingdom shall ensure compliance with paragraph (1), including as regards the required powers of its judicial and administrative authorities to disapply inconsistent or incompatible domestic provisions, through domestic primary legislation.' This is, in domestic legal terms, an intrusive provision and a potentially far-reaching one. However, it is enshrined only in the WA, an international treaty. It is not mirrored specifically in either EUWA 2018 or EUWAA 2020. Since it is a provision of international law that has not been specifically incorporated into UK law, the UK dualist theory applies. Thus, are its efficacy and enforcement confined to the realms of politics, diplomacy, municipal elections and, possibly, international courts? The answer, again, appears to be no. EUWAA 2020 is designed to give effect in UK domestic law to the WA. By 2020, EUWA 2018 was no longer capable of giving adequate effect in domestic law to all aspects of Brexit. EUWAA 2020, with its associated amendments of EUWA 2018, was an essential statutory measure, required to reflect the radically changed Brexit landscape which materialized post-2018. Crucially, section 7A EUWA 2018

${ }^{20}$ Eg, Fransson $v$ Sweden, C 617/10, Judgment of the Court (Grand Chamber) 26 February 2013. 
(introduced by s 5 of EUWAA 2020) provides in material part that '(1) Subsection (2) applies to - . . the Ireland/Northern Ireland Protocol'. The critical parts of section 7A are subsections (2) and (3). ${ }^{21}$ Albeit by a somewhat cumbersome drafting route, section 7A appears to subject all measures of UK legislation to all rights (etc) and all remedies (etc) referable to the WA, to give effect thereto in UK domestic law and to require their enforcement in legal proceedings in that jurisdiction.

Given that the CFR has a clearly identifiable degree of survival under the $\mathrm{WA}$, and having regard to the indisputable relationship between the WA and EUWAA 2020, the operation of the CFR with regard to issues arising under the WA (and, hence, the Protocol) seems clearly arguable. Although there is a discernible tension between sections 5(4) and 7A EUWA 2018, the exercise of reading section 5(4) EUWA 2018 in the context of the jigsaw of other provisions highlighted above reveals that the demise of the CFR has not been achieved. Ironically, given the intricacies involved, the CFR could conceivably receive greater attention in the UK, via the Protocol, than ever before. (Of course, while I have outlined certain indications pointing towards an interpretation which dilutes the superficially uncompromising language of section 5(4), full adversarial argument and authoritative judicial construction in an appropriate case will be required.)

\subsection{Measuring the Loss When the CFR Does Not Apply Directly}

Where the CFR does not apply in the UK post-Brexit, its repeal will have two predictable impacts on the legal protection of rights. First, as the rights protected by the CFR are more extensive than those enshrined in the ECHR (protected in domestic law via the HRA), human rights protection seems destined to diminish across the UK as a whole. The HRA survives (for the moment), continuing to be a major source of directly effective human rights protection in the UK. However, as the CFR is of demonstrably greater reach than the ECHR, where the former no longer applies UK citizens will not have the protection of the CFR's additional rights, the soi-disant 'added value'. These include, in particular: the specific rights of the child; $;^{22}$ the array of social protections contained in Title IV; ${ }^{23}$ freedom to conduct a business; ${ }^{24}$ the strong anti-discrimination provisions; ${ }^{25}$

${ }^{21}$ Examined in detail in Chapters 3, 9 and 10.

22 Art 24.

${ }^{23}$ Arts 27 to 38 .

24 Art 16.

25 Art 21. 
freedom of the arts and sciences; ${ }^{26}$ a right of conscientious objection; ${ }^{27}$ freedom to choose an occupation; ${ }^{28}$ a right to asylum and against refoulement; ${ }^{29}$ a right to data protection; ${ }^{30}$ the prohibition against human trafficking, ${ }^{31}$ a right to marry not restricted to different-sex couples; ${ }^{32}$ the right to physical and mental integrity; ${ }^{33}$ and a guarantee of human dignity. ${ }^{34}$ This is an impressive list indeed of deceased rights. ${ }^{35}$

Second, while some of the CFR's additional rights and protections are, as we have seen, recognized in certain measures of UK domestic law (eg, data protection and protection from human trafficking) or in the ECtHR jurisprudence (eg, certain types of physical and mental integrity), others are likely to evaporate, a particular and worrying illustration being the more expansive rights of the child. Furthermore, to enshrine 'parallel' rights in UK domestic law may not benefit from the expansion and fortification of the CFR which, historically, have emerged from the progressive interpretation of the CJEU. Furthermore, future EU legislative measures of expansion and fortification will not apply in the UK.

Third, the abolition of the CFR will give rise to a significant limitation in the matter of available judicial remedies for human rights violations. Under the scheme of the HRA, if a provision of primary legislation cannot be read and given effect in a manner compatible with the Convention rights, the court is empowered to make a declaration of incompatibility. ${ }^{36}$ This remedial order does not affect the validity, continuing operation or enforcement of the impugned statutory provision. As regards secondary legislation, a judicial order of striking down or setting aside is possible. ${ }^{37}$ In contrast, as the CFR had the status of supreme EU law in the UK legal system, it had to prevail over any conflicting UK law. Thus, a judicial decision, reflected in an appropriate remedy, that a measure of UK law was incompatible with the CFR would

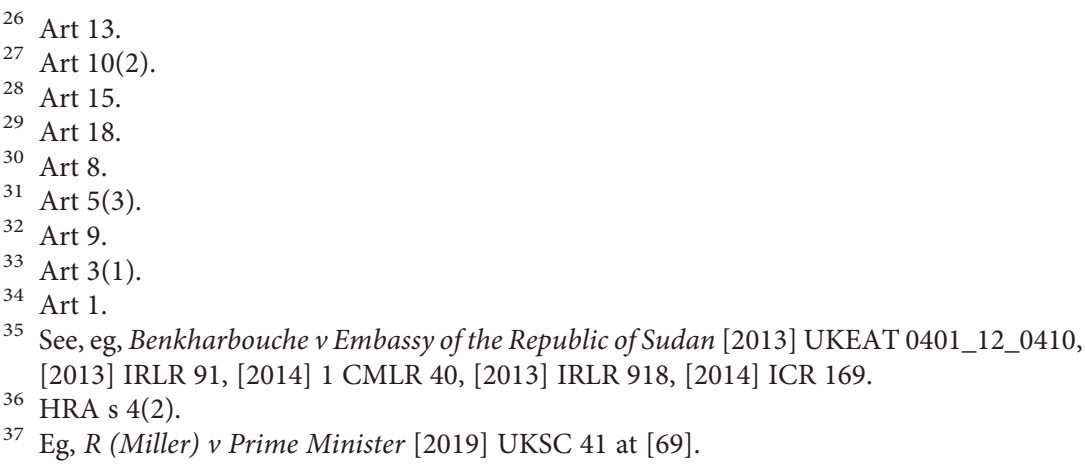


nullify the relevant UK law immediately. Where the CFR does not apply, this will no longer be possible.

More generally, the UK's retreat from the CFR is likely to have a negative impact on the culture of human rights protection in the UK. It is beyond plausible dispute that, even where there is theoretically strong human rights protection in the laws of any nation, the mindset of its citizens, invariably shaped to some extent by the general culture and philosophy promoted by the government of the day, elected by a majority of voters, is an essential tool in ensuring effective rights protection in practice. It seems highly likely that the removal of the CFR from large parts of UK law will have a negative impact in this respect. This could prove to be the most damaging consequence of all.

The progressive evaporation of the CFR must also be seen in the context of what appears to be a general decline in the UK's rule-of-law culture. Protection of the rule of law is a critical component of, and support for, the protection of human rights. Yet there are already legitimate worries about the present and future rule-of-law culture in the UK, with at least four reasons to be concerned, at the time of writing. First, several decisions of the UK courts on Brexit-related issues have provoked a vitriolic outcry against the judiciary, one of unparalleled proportions in modern-day Britain, in which senior government figures were prominent. Second, the government, following the latest of these decisions, which it comprehensively lost, quickly announced that there would be a fundamental judicial review (which has now been completed). ${ }^{38}$ Despite the review recommending only minimal changes, the government announced that it would nevertheless be proceeding with more radical 'reforms' aimed at limiting judicial review in the future. ${ }^{39}$ Third, in December 2020, the government announced a review of the HRA, with terms of reference seemingly indicating a desire to reduce protections in various respects. ${ }^{40}$ Fourth, the UK Internal Market Bill, published in September 2020, contained a provision $^{41}$ (subsequently withdrawn

38 See Ministry of Justice, Judicial Review Reform, 18 March 2021 (www.gov.uk/govern ment/consultations/judicial-review-reform).

39 House of Commons library, Judicial Review Reform article, published 1 April 2021 (https://commonslibrary.parliament.uk/judicial-review-reform/).

40 See Hansard of 7 December 2020 (https://hansard.parliament.uk/commons/2020-12-07/ debates/20120741000012/IndependentHumanRightsActReview) and the Ministry of Justice publication of 7 December 2020 relating to the HRA Review (www.gov.uk/guid ance/independent-human-rights-act-review).

41 Clauses 42 and 43. 
because of opposition in the House of Lords) which equipped government with powers to breach international law, including the WA.

\subsection{Conclusion}

Pre-Brexit, the CFR was something of a sleeping beauty in the UK legal system. Post-Brexit, will it experience an unexpected and perhaps unintended reawakening? It seems unlikely that the CFR will evaporate entirely from UK law, whether because of its influence in the context of 'retained EU law' or because of its importance in respect of the Protocol, or both. Intriguingly, the CFR could conceivably be of greater future influence in the UK than it was pre-Brexit. But is it destined to fade or flourish? The extent of the CFR's post-Brexit influence in the UK will depend significantly on three factors. The first is the innovation and creativity of UK lawyers and judges, which were especially evident as regards the ECHR in the pre-HRA era of the 1980s and 1990s. The second is the extent to which disputes that eventually arise for adjudication before the CJEU and the international arbitration panel are decided in part by reference to the CFR. The third is the future rule-of-law culture in the UK in which the CFR will be attempting to operate. Effective human rights protection, particularly in a country which has no written constitution, will be heavily dependent on a strong rule-of law-culture. What the future holds for this culture in the UK is uncertain, but it is a matter of legitimate concern, not least because of the cold climate in which the CFR will operate in those situations where it applies. To change the metaphor, there are signs that the CFR will find itself swimming in murky waters, ever willing but maybe floundering. 
